\title{
EDUKASI TENTANG MANAJEMEN TERPADU BALITA \\ SAKIT UNTUK PENCEGAHAN ISPA TERHADAP \\ PENGETAHUTAN IBU BALITA DI PUSKESMAS GROGOL
}

\author{
Devi Pramita Sari ${ }^{1}$, Rahaju Muljo Wulandari ${ }^{2}$, Afianto Reza ${ }^{3}$ \\ Program Studi D III Rekam Medis Fakultas Ilmu Kesehatan UDB \\ (devi_sari@udb.ac.id)
}

\begin{abstract}
ABSTRAK
Latar Belakang : Infeksi Saluran Pernafasan Akut (ISPA) merupakan penyakit radang akut saluran pernafasan atas maupun bawah yang disebabkan infeksi bakteri, virus, riketsia, tanpa atau disertai radang parenkim paru. Pemberian edukasi pada ibu balita dilakukan menggunakan metode brainstorming dan buzz group tentang edukasi manajemen kesehatan untuk pencegahan ISPA.

Tujuan : Tujuan penelitian ini adalah mengetahui pengaruh edukasi manajemen terpadu balita sakit untuk pencegahan ISPA dengan metode brainstorming dan buzz group terhadap pengetahuan ibu balita Di Puskesmas Grogol.

Metode : Penelitian di Puskesmas Grogol. Populasi dan sampel sebanyak 100 sampel ibu balita ISPA yang memeriksakan balita di Puskesmas Grogol yang diambil dengan tekhnik total sampel. Analisis data menggunakan uji statistik yang digunakan paired sample t-test. Data pengetahuan ibu mengenai pengetahuan ibu balita tentang MTBS Balita Sakit Untuk Pencegahan ISPA yang dikumpulkan menggunakan kuesioner pretest dan posttest.

Hasil : Hasil rerata 73,10 sebelum diberikan edukasi dan setelah diberikan edukasi pencegahan stunting didapatkan rerata 84,40 . Dari hasil penelitian nilai signifikan p sebesar $0.000<0,05$.

Simpulan : Ada pengaruh edukasi manajemen terpadu balita sakit untuk pencegahan ISPA dengan metode brainstorming dan buzz group terhadap pengetahuan ibu balita Di Puskesmas Grogol.
\end{abstract}

Kata kunci : ISPA, Manajemen Terpadu Balita Sakit

\section{Education On Integrated Management Of Sick Toodler For Arrival Prevention To Knowledge Of Mother At The Grogol Puskesmas}

\begin{abstract}
Background: Acute Respiratory Infection (ISPA) is an acute inflammatory disease of the upper and lower respiratory tract caused by infection with bacteria, viruses, rickets, without or accompanied by inflammation of the lung parenchyma. Education for mothers of children under five is carried out using the brainstorming method and buzz group on health management education for the prevention of ISPA.
\end{abstract}



sakit untuk pencegahan ISPA dengan metode brainstorming dan buzz group terhadap pengetahuan ibu balita Di Puskesmas Grogol )

Objective: The purpose of this study was to determine the effect of integrated management education for sick toddlers for the prevention of ISPA with the brainstorming method and buzz group on the knowledge of mothers toodler at Grogol Puskesmas.

Method: Research at the Grogol Puskesmas. The population and sample were 100 samples of mothers of toodler with ISPA who examined their toddlers at the Grogol Puskesmas which were taken using a total sample technique. Data analysis using statistical tests used paired sample t-test. Maternal knowledge data regarding the knowledge of mothers under five about IMCI for children with illness for the prevention of ISPA were collected using pretest and posttest questionnaires.

Results: The mean results were 73.10 before being given education and after being given stunting prevention education, the mean was 84.40. From the research results, the significant value of $p$ is $0.000<0.05$.

Conclusion: There is an effect of integrated management education for sick toddlers for the prevention of ISPA with the brainstorming method and buzz group on the knowledge of mothers toodler at Grogol Puskesmas.

\section{Keywords: ISPA, Integrated Management of Sick Toddlers}

\section{PENDAHULUAN}

Infeksi Saluran Pernafasan Akut (ISPA) merupakan penyakit yang sering dijumpai dengan manifestasi ringan sampai berat (Andriani dkk, 2018). Gejalanya meliputi demam, batuk, dan sering juga nyeri tenggorok, pilek, sesak napas, mengi, atau kesulitan bernapas. ISPA biasanya berlangsung lebih dari 14 hari (Dary dkk, 2017). ISPA yang mengenai jaringan paru-paru atau ISPA berat, dapat menjadi pneumonia. Pneumonia merupakan penyakit infeksi penyebab kematian utama, terutama pada balita (Lidia dkk,2018). Infeksi saluran pernapasan atas menyebar dari satu struktur ke struktur lain karena terhimpitnya membran mukus yang membentuk garis lurus pada seluruh sistem yang disebabkan oleh beberapa faktor (Sofia,2018).

Secara umum ada 3 (tiga) faktor risiko terjadinya ISPA yaitu faktor lingkungan, faktor individu anak, serta faktor perilaku (Syahidi dkk, 2016). Faktor lingkungan meliputi pencemaran udara dalam rumah, kondisi fisik rumah, dan kepadatan hunian rumah (Dongky dkk,2016). Faktor individu anak meliputi umur anak, berat badan lahir, status gizi, vitamin A, dan status imunisasi (Wahyuningsih dkk, 2017). Sedangkan faktor perilaku berhubungan dengan pencegahan dan penanggulangan penyakit ISPA pada bayi dan balita dalam hal ini adalah praktek penanganan ISPA di keluarga baik yang dilakukan oleh ibu ataupun anggota keluarga lainnya (Lebuan dkk, 2017). Faktor lingkungan juga dapat disebabkan dari pencemaran udara dalam rumah seperti asap rokok, asap dari dapur karena memasak dengan kayu bakar serta kebiasaan menggunakan obat nyamuk bakar didalam rumah (Sofia,2017). Balita merupakan usia dimana anak belum mampu untuk mempertahankan diri terhadap serangan penyakit (Indah, 2020). Peranan orang tua dalam membentuk tindakan pencegahan ISPA pada balita sangat dibutuhkan (Roso, 2015). Hal ini terbukti dari beberapa hasil penelitian yang sudah dilakukan, dan berdasarkan beberapa hasil penelitian yang 
sudah ada tidak dapat dipungkiri, bahwa angka kejadian ISPA masih menjadi permasalahan kesehatan dan merupakan penyakit yang banyak menyerang balita (Dary dkk, 2018).

Pencegahan ISPA salah satunya adalah dengan edukasi manajemen terpadu balita sakit pada ibu balita penderita ISPA (Hidayati dkk,2019). Edukasi manajemen terpadu balita sakit untuk pencegahan ISPA pada balita meliputi pengetahuan tentang penyakit ISPA, gejala ISPA, klasifikasi ISPA, pencegahan penyakit ISPA, perbaikan gizi penderita ISPA, tindakan dan pengobatan ISPA (Atira,2018). Edukasi pencegahan ISPA pada hakikatnya adalah suatu kegiatan atau usaha menyampaikan pesan kepada ibu balita dengan harapan agar bisa memperoleh pengetahuan yang lebih baik sehingga dapat berpengaruh sikap dan perilaku (Sundari,2016). Beberapa faktor yang mempengaruhi proses edukasi yaitu metode, materi atau pesannya, pemateri yang melakukannya, dan alat-alat bantu atau media yang digunakan untuk menyampaikan pesan (Novriandra dkk,2018). Edukasi pencegahan ISPA tidak dapat lepas dari metode yang menarik salah satunya adalah metode brainstorming dan buzz group sehingga pesan-pesan yang disampaikan dapat lebih menarik dan dipahami, serta dapat mengadopsi perilaku positif (Qiyaam dkk, 2016).

Puskesmas Grogol ada di Kecamatan Grogol, Kabupaten Sukoharjo. ISPA menjadi salah satu permasalahan balita di Puskesmas Grogol. Data di Puskesmas Grogol pada bulan Juli tahun 2019 ada 1 dari 5 balita menderita ISPA. Hasil wawancara dengan bidan koordinator anak di Puskesmas Grogol, diketahui bahwa ISPA merupakan penyebab kesakitan paling banyak pada balita di Puskesmas Grogol. Kondisi yang ada pada balita yang datang ke Puskesmas Grogol yaitu demam, batuk, dan sering juga nyeri tenggorok, pilek, sesak napas, dan kesulitan bernapas. Balita ISPA tersebut disebabkan oleh adanya pengetahuan yang kurang pada ibu balita tentang manajemen terpadu balita sakit. Kondisi ibu balita yang datang tersebut juga kurangnya pengetahuan tentang gejala ISPA, pemberian gizi pada balita ISPA, tindakan serta pengobatan balita penderita ISPA. Penelitian ini bertujuan untuk memberikan pengetahuan dan melakukan pendampingan pada ibu balita penderita ISPA di Wilayah Puskesmas Grogol tentang manajemen balita terpadu sakit meliputi pengetahuan tentang penyakit ISPA, gejala ISPA, klasifikasi ISPA, pencegahan penyakit ISPA, perbaikan gizi penderita ISPA, tindakan dan pengobatan ISPA. Hal ini yang menjadi landasan untuk melakukan penelitian dosen pemula dengan judul "Edukasi Tentang Manajemen Terpadu Balita Sakit Untuk Pencegahan ISPA Terhadap Pengetahuan Ibu Balita Di Puskesmas Grogol"

\section{METODE PENELITIAN}

Penelitian ini merupakan studi pra-eksperimental dengan rancangan one group pretest-posttest design. Pengukuran pengetahuan ibu dilakukan sebelum dan sesudah perlakuan. Penelitian dilakukan di Puskesmas Grogol. Puskesmas ini dipilih karena menjadi salah satu puskesmas yang fokus utama penanganan ISPA dan jumlah kesakitan ISPA pada balita banyak yang berkunjung ke puskesmas. Variabel bebas pada penelitian ini adalah edukasi tentang manajemen terpadu balita sakit untuk pencegahan ISPA dengan metode brainstorming dan buzz group, sedangkan varibel terikat adalah pengetahuan ibu balita penderita ISPA di Puskesmas Grogol. Populasi dan sampel sebanyak 100 ibu balita penderita ISPA yang berkunjung di Puskesmas Grogol yang diambil dengan tekhnik total sampel. Pengumpulan data menggunakan kuesioner sebelum dan sesudah pemberian edukasi dengan pretest-posttest. Pada pemberian edukasi dengan metode brainstorming enumerator pada awalnya memancing dengan suatu masalah yaitu 
ISPA. Setelah masalah tersebut disampaikan, setiap peserta memberikan jawaban dan tanggapan. Pada pemberian edukasi dengan metode buzz group maka pemberian edukasi dilakukan dengan cara kelompok langsung dibagi menjadi kelompok-kelompok kecil (buzz group) yang kemudian diberi suatu permasalahan yang sama atau tidak sama dengan kelompok lain. Masing-masing kelompok mendiskusikan masalah tersebut. Selanjutnya hasil dari tiap kelompok didiskusikan kembali dan dicari kesimpulannya. Alat bantu yang digunakan pada metode brainstorming adalah power point dan buku saku mengenai penyebab dan cara pencegahan ISPA tentang manajemen terpadu balita sakit. Analisis univariat dilakukan untuk mengetahui karakteristik ibu yang memiliki anak penderita ISPA serta pengetahuan ibu tentang ISPA pada tahap pretest dan posttest. Analisis bivariat dilakukan dengan uji statistik paired sample t-test.

\section{HASIL DAN PEMBAHASAN}

\section{Hasil}

1. Perolehan Analisis Univariat Pre Test Dan Post Test Pada Edukasi Tentang Manajemen Terpadu Balita Sakit Untuk Pencegahan ISPA Terhadap Pengetahuan Ibu Balita Di Puskesmas Grogol dapat dilihat di tabel ini : Tabel 1. Analisis Univariat Pre Test dan Post Test Hasil Edukasi Tentang Manajemen Terpadu Balita Sakit Untuk Pencegahan ISPA Terhadap Pengetahuan Ibu Balita Di Puskesmas Grogol

\begin{tabular}{llcc}
\hline No & \multicolumn{1}{c}{ Analisis } & Hasil \\
\cline { 3 - 4 } & & Pre Test & Post Test \\
\hline 1. & Mean & 73,10 & 84,40 \\
2. & Median & 75 & 85 \\
3. & Modus & 85 & 90 \\
4. & Nilai Tertinggi & 90 & 100 \\
5. & Nilai Terendah & 40 & 60 \\
\hline
\end{tabular}

Berdasarkan tabel 1 didapatkan hasil nilai pre test pengetahuan ibu balita sebelum diberikan edukasi manajemen terpadu balita sakit untuk pencegahan ISPA terhadap pengetahuan ibu balita penderita ISPA Di Puskesmas Grogol pada 100 responden dapat diketahui nilai rata-rata (mean) 73,10 , median 75 , modus 85 , nilai tertinggi pre test 90 , dan nilai terendah pre test 40 . Hasil nilai post test pengetahuan ibu balita sesudah diberikan edukasi manajemen terpadu balita sakit untuk pencegahan ISPA terhadap pengetahuan ibu balita penderita ISPA Di Puskesmas Grogol pada 100 responden dapat diketahui mean 84,40 , median 85 , modus 90 , nilai tertinggi post test 100, dan nilai terendah post test 60 .

Tabel 2. Analisis Hasil Perolehan Nilai Pre Test dan Posttest Pada edukasi manajemen terpadu balita sakit untuk pencegahan ISPA terhadap pengetahuan ibu balita penderita ISPA Di Puskesmas Grogol

\begin{tabular}{|c|c|c|c|c|c|c|}
\hline \multirow{3}{*}{$\begin{array}{c}\text { Perlakuan } \\
\text { Test }\end{array}$} & \multicolumn{6}{|c|}{ Hasil } \\
\hline & \multicolumn{2}{|c|}{ Baik } & \multicolumn{2}{|c|}{ Buruk } & \multicolumn{2}{|c|}{ Total } \\
\hline & Frekuensi & $\begin{array}{c}\text { Prosentase } \\
(\%)\end{array}$ & Frekunsi & $\begin{array}{c}\text { Prosentase } \\
(\%)\end{array}$ & Frekunensi & $\begin{array}{c}\text { Prosentase } \\
(\%)\end{array}$ \\
\hline Pre Test & 90 & 90 & 10 & 10 & 100 & 100 \\
\hline Post Test & 100 & 100 & 0 & 0 & 100 & 100 \\
\hline
\end{tabular}

Berdasarkan tabel 2 didapatkan hasil nilai pre test dan post test pada edukasi manajemen terpadu balita sakit untuk pencegahan ISPA terhadap pengetahuan ibu balita penderita ISPA Di Puskesmas Grogol dapat 
disimpulkan bahwa semua responden mengalami peningkatan pengetahuan dilihat dari perubahan nilai pre test dan post test yang didapat ibu balita. Nilai pre test ibu balita yang baik ada 90 responden (90\%) sedangkan yang buruk ada 10 responden (10\%). Pada hasil post test semua responden ibu balita nilai post testnya baik semua sebanyak 100 responden (100\%).

2. Analisis bivariat dilakukan untuk mengetahui pengaruh edukasi manajemen terpadu balita sakit untuk pencegahan ISPA terhadap pengetahuan ibu balita penderita ISPA Di Puskesmas Grogol dengan metode Brainstorming dan Buzz Group. Analisis yang digunakan adalah dengan menggunakan uji normalitas Saphiro-wilk terlebih dahulu, didapatkan hasil sebagai berikut:

Tabel 3. Hasil uji normalitas nilai sebelum dan sesudah dilakukan edukasi manajemen terpadu balita sakit untuk pencegahan ISPA TerhadapPengetahuan Ibu Balita Di Puskesmas Grogol dengan Kolmogorov Smirnov

\begin{tabular}{lc}
\hline \multicolumn{1}{c}{ Pencapaian } & p (Sig.) \\
\hline Nilai Sebelum (Pre Test) & 0,000 \\
Nilai Sesudah (Post Test) & 0,000 \\
\hline
\end{tabular}

Berdasarkan tabel 3 didapatkan hasil nilai $\mathrm{p}$ (sig) pre test dan post test pada edukasi manajemen terpadu balita sakit untuk pencegahan ISPA terhadap pengetahuan ibu balita penderita ISPA Di Puskesmas Grogol dengan metode Brainstorming dan Buzz Group sama yaitu nilai p (sig) $0,000<0,05$ sehigga berarti ada pengaruh edukasi manajemen terpadu balita sakit untuk pencegahan ISPA terhadap pengetahuan ibu balita penderita ISPA Di Puskesmas Grogol dengan metode Brainstorming dan Buzz Group.

3. Analisis lanjutan yang digunakan adalah uji $\mathrm{T}$ berpasangan (paired $t$-test) dan didapatkan hasil sebagai berikut :

Tabel 4. Pengaruh edukasi manajemen terpadu balita sakit untuk pencegahan ISPA terhadap pengetahuan ibu balita penderita ISPA Di Puskesmas Grogol dengan metode Brainstorming dan Buzz Group

\begin{tabular}{lcccc}
\hline $\begin{array}{l}\text { Nilai Pre Test } \\
\text { Dan Post Test }\end{array}$ & Mean & $\begin{array}{c}\text { Standar } \\
\text { Deviasi }\end{array}$ & t & $\begin{array}{c}\text { Sig. } \\
\text { (2-tailled) }\end{array}$ \\
\cline { 2 - 5 } & $-11,30$ & 5,2522 & $-21,515$ & 0,000 \\
\hline
\end{tabular}

Berdasarkan tabel 4 didapatkan hasil nilai $\mathrm{p}$ (sig) pre test dan post test dengan edukasi manajemen terpadu balita sakit untuk pencegahan ISPA terhadap pengetahuan ibu balita penderita ISPA Di Puskesmas Grogol dengan metode Brainstorming dan Buzz Group didapatkan hasil dari 100 responden terjadi peningkatan rerata sebesar 11,30, standar deviasi 5,2522, dan thitung sebesar 21,515. Selain itu juga didapatkan hasil nilai signifikan $\mathrm{p}$ sebesar $0.000<0,05$. Jadi dapat disimpulkan ada pengaruh edukasi manajemen terpadu balita sakit untuk pencegahan ISPA terhadap pengetahuan ibu balita penderita ISPA Di Puskesmas Grogol. 


\section{Pembahasan}

Berdasarkan uji paired sample t-test diperoleh nilai signifikan p $(0,000)<$ $\alpha(0,05)$ sehingga diketahui ada pengaruh edukasi pencegahan stunting tentang satu pilar akses pangan bergizi dengan metode brainstorming terhadap pengetahuan ibu baduta Di Taman Sari Timur. Terjadi peningkatan rerata skor pengetahuan ibu dari 73,10 menjadi 84,40 dengan adanya peningkatan skor, baik pada nilai tertinggi maupun nilai terendah (Tabel 1). Hal tersebut sejalan dengan penelitian Atira (2018) yang menyatakan bahwa intervensi manajemen terpadu balita sakit dapat meningkatkan skor pengetahuan pada ibu balita penderita ISPA. Pada penelitian Qiyaam, dkk (2016) diketahui efektivitas media audiovisual sebagai media penyuluhan kesehatan terhadap peningkatan pengetahuan sebelum dan sesudah dilakukan intervensi. Pengaruh pemberian edukasi dengan metode brainstorming dan buzz group dapat memberikan peningkatan pengetahuan lebih baik mengenai pengetahuan manajemen terpadu balita sakit (Dary dkk, 2018).

Edukasi dengan metode brainstorming dan buzz group mengharuskan semua subjek penelitian terlibat aktif untuk menyatakan pendapat dan pengalamannya serta membahas materi mengenai manajemen terpadu balita sakit sebagai upaya pencegahan balita ISPA hingga memperoleh kesimpulan yang sesuai. Prinsip belajar dengan cara menghubung-hubungkan dengan pengalaman atau perilaku lama menyebabkan pesan akan lebih mudah diterima dan dipahami (Widianingsih, 2018). Subjek penelitian yang telah diberikan suatu objek atau stimulus pada proses selanjutnya akan memiliki atau bersikap terhadap stimulus atau objek tersebut (Hidayati dkk,2019). Dalam penelitian ini penyuluhan dengan metode brainstorming dan buzz group merupakan stimulus atau objek yang dapat memberi pengaruh pada responden untuk bersikap sesuai dengan pesan atau isi dari diskusi yaitu pengetahuan mengenai pencegahan stunting tentang satu pilar akses pangan bergizi (Novesar dkk, 2019).

Metode brainstorming (curah pendapat) ini sama dengan metode diskusi kelompok namun pada metode brainstorming, pemimpin kelompok memancing dengan satu masalah kemudian tiap peserta memberikan jawaban-jawaban atau tanggapan (Indah dkk,2020). Tanggapan atau jawaban- jawaban tersebut ditampung dan ditulis dalam flipchart atau papan tulis (Lidia dkk,2018). Sebelum semua peserta mencurahkan pendapatnya, tidak boleh diberi komentar oleh siapapun. Setelah semua anggota mengeluarkan pendapatnya maka tiap anggota dipersilakan untuk memberikan komentar sehingga akhirnya terjadilah diskusi. Pada penelitian yang dilakukan di Bogor menunjukkan bahwa brainstorming efektif dalam meningkatkan pengetahuan ibu balita (Andriani dkk,2018).

\section{SIMPULAN DAN SARAN}

\section{Simpulan}

Pemberian edukasi manajemen terpadu balita sakit untuk pencegahan ISPA terhadap pengetahuan ibu balita penderita ISPA Di Puskesmas Grogol dengan metode Brainstorming dan Buzz Group dinilai bermanfaat karena terjadi peningkatan rerata skor pengetahuan ibu dari sebelum dan sesudah edukasi dari 
73,10 menjadi 84,40. Berdasarkan uji paired sample t-test juga diperoleh nilai signifikan $\mathrm{p}(0,000)<\alpha(0,05)$ sehingga disimpulkan ada pengaruh edukasi manajemen terpadu balita sakit untuk pencegahan ISPA terhadap pengetahuan ibu balita penderita ISPA Di Puskesmas Grogol.

\section{Saran}

Saran sebaiknya melakukan edukasi manajemen terpadu balita sakit untuk pencegahan ISPA menggunakan metode brainstorming dan buzz group dengan target sasaran yang lebih luas. Saran bagi peneliti lain yaitu untuk melakukan penelitian dengan mengendalikan lebih banyak faktor yang menggangu hasil penelitian serta melakukan evaluasi pengetahuan manajemen terpadu balita sakit ibu setelah 1-2 bulan pelaksanaan intervensi.

\section{DAFTAR PUSTAKA}

Andriani, dkk. 2018. Gambaran Karakteristik Pengetahuan Ibu yang Memiliki Balita dengan ISPA di Puskesmas Siliwangi Garut. Jurnal Medika Cendikia. Vol 5. N0 2. Bandung: Universitas Padjadjaran.

Atira, Cinta. 2018. Hubungan Tingkat Pendidikan Ibu Dengan Kejadian Infeksi Saluran Pernapasan Atas Pada Balita. Jurnal Ilmiah Citra Delima. Vol 2. No 1. Bangka Belitung : Stikes Citra Delima Bangka Belitung

Dary, dkk. 2018. Strategi Tenaga Kesehatan Dalam Menurunkan Angka Kejadian ISPA Pada Balita Di Wilayah Binaan Puskesmas Getasan. Jurnal KesMaDaSka. Vol 1. No. 2. Salatiga : Fakultas Kedokteran Dan Ilmu Kesehatan Universitas Kristen Satyawacana

Dongky, dkk. 2016. Faktor Resiko Lingkungan Fisik Rumah Dengan Kejadian ISPA Di Kelurahan Takatidung Polewali Mandar. Unnes Journal of Public Health. Vol 5. No 4. Semarang : Unnes

Hidayati, dkk. 2019. Pelayanan Puskesmas Berbasis Manajemen Terpadu Balita Sakit Dengan Kejadian Pneumonia Balita. Jurnal Kesehatan Masyarakat. Vol 7. No 1. Semarang : Universitas Negeri Semarang

Indah, dkk. 2020. Perbedaan Upaya Pencegahan ISPA oleh Ibu Balita Sebelum dan Sesudah Dilakukan Program Manajemen Terpadu Balita Sakit di Puskesmas Dempet Kabupaten Demak. Jurnal Keperawatan Dan Kesehatan Masyarakat Cendekia Utama. Vol 1. No 1.

Lebuan, dkk. 2017. Faktor Yang Berhubungan Dengan Infeksi Saluran Pernapasan Akut Pada Siswa Taman Kanak-Kanak Di Kelurahan Dangin Puri Kecamatan Denpasar Timur Tahun 2014. E-Jurnal Medika. Vol 6. No 6. Denpasar : Universitas Udayana

Lidia, dkk. 2018. Pengetahuan Keluarga Berhubungan Dengan Perilaku Pencegahan ISPA Pada Balita. Jurnal Ilmiah Permas. Vol 8. NO 2. Kendal : STIKES Kendal

Novesar, dkk. 2019. Pola Kejadian ISPA Pada Balita Di Wilayah Kerja Puskessmas Anak Air Padang Tahun 2019. Jurnal Kesehatan Andalas. Vol 3. No 3. Sumatra Barat : Universitas Andalas 
Novriandra, dkk. 2015. Perbandingan Efektifitas Pendidikan Kesehatan Tentang ISPA Terhadap Pengetahuan Dan Kemampuan Ibu Merawat Balita ISPA Antara Puskesmas Padang Pasir Dengan Puskesmas Pauh. Jurnal Sains Farmasi \& Klinis. Vol 1. No 2. Sumatra Barat : Fakultas Farmasi Universitas Andalas Bekerjasama Dengan Ikatan Apoteker Indonesia

Qiyaam, dkk. 2016. Tingkat Pengetahuan Ibu Terhadap Penyakit ISPA (Infeksi Saluran Pernapasan Akut) Pada Balita Di Puskesmas Paruga Kota Bima Tahun 2016. Jurnal Ilmiah Ibnu Sina. Vol 1. No 2. Mataram : Universitas Muhammadiyah Mataram

Riyanto, dkk. 2016. Pengaruh Asap Rokok Terhadap Frekuensi Terjadinya Penyakit ISPA pada Balita di Puskesmas Kedung Banteng Banyumas. Jurnal Medisains. Vol 14. No. 3. Purwokerto : Fakultas Kedokteran Universitas Muhammadiyah Purwokerto

Roso, Cipto. 2015. Peran Keluarga Prasejahtera Dengan Upaya Pencegahan Infeksi Saluran Pernafasan Akut (ISPA) Pada Balita Di Desa Depok Kecamatan Kandeman Kabupaten Batang. Jurnal Keperawatan Fikes. Vol 8. NO 2. Depok: STIKES Keperawatan

Sofia. 2017. Faktor Risiko Lingkungan Dengan Kejadian Ispa Pada Balita Di Wilayah Kerja Puskesmas Ingin Jaya Kabupaten Aceh Besar. AcTion Jurnal. Vol 2. No.1. Aceh Besar : Poltekkes Kemenkes Aceh Besar

Sundari, Siti. 2016. Perilaku Tidak Sehat Ibu Yang Menjadi Faktor Resiko Terjadinya ISPA Pneumonia Pada Balita. Jurnal Pendidikan Sains. Vol 2. No 3. Malang : Poltekes Kemenkes Malang

Syahidi, dkk. 2016. Faktor-faktor yang Mempengaruhi Kejadian Infeksi Saluran Pernapasan Akut (ISPA) pada Anak Berumur 12-59 Bulan di Puskesmas Kelurahan Tebet Barat Kecamatan Tebet Jakarta Selatan Tahun 2013. Jurnal Epidemiologi Kesehatan Indonesia. Vol 1. No. 1. Jakarta : Fakultas Ilmu Kesehatan Universitas Indonesia

Wahyuningsih, dkk. 2017. Infeksi Saluran Pernapasan Akut (ISPA) Pada Balita Di Wilayah Pesisir Desa Kore Kecamatan Sanggar Kabupaten Bima. Jurnal Higiene. Vol 3. No. 2. Makasar: Jurusan Kesehatan Masyarakat Universitas Islam Negeri Alauddin Makasar.

Widaningsih. 2018. Metode Edukasi Kesehatan Dan Manajemen Investigasi Infeksi Saluran Pernapasan Akut (ISPA). Jurnal IJONHS. Vol 3. No. 1. Jakarta : Universitas Esa Unggul 